
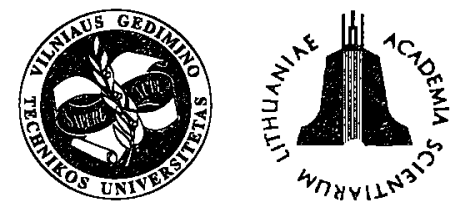

ISSN 1648-4142 TRANSPORT

http:/www.vtu.lt/english/editions

TRANSPORT - 2003, Vol XVIII, No 4, 189-192

\title{
STUDY ON OCCUPATIONAL AND NONOCCUPATIONAL RISK FACTORS AND HEALTH OF MOTOR TRANSPORT WORKERS*
}

\author{
Vytautas Obelenis, Daiva Gedgaudienè \\ Dept of Environmental and Occupational Medicine, Kaunas Medical University, \\ A. Mickevičiaus g.9, LT-3000 Kaunas, Lithuania.E-mail: aplink@kmu.lt
}

Received 200301 27; accepted 20030212

\begin{abstract}
The study on work conditions, lifestyle, psychosocial factors and health was carried out in three different urban motor transport companies. 788 workers of the main occupations were interviewed using a questionnaire. The main occupational hazards are low air temperature, draughts, exposure to diesel fuel, cooling oil, noise, vibration, musculoskeletal exertion. Workers do not lead a healthy lifestyle: $46,0 \%$ - are smokers, $83,0 \%$ - use alcohol, $53,0 \%$ are physically inactive, $82,0 \%$ lead a malnutrition regimen, $27,0 \%$ experience stressful situations at work every day. Musculoskeletal disorders make up 46,2\%, respiratory 22,2\%, gastrointestinal 17,3\% and central nervous system dysfunction 32,2\%. Musculoskeletal disorders are related to poor ergonomic and workplace design, long working hours, senior age and long professional work experience $(p<0,05-0,002)$.
\end{abstract}

Keywords: motor transport workers, workplace conditions, lifestyle, psychosocial factors, health.

\section{Introduction}

Work conditions, ergonomic, lifestyle, psychological and social factors have an impact on health, workability, professional reliability of motor transport workers and safety of traffic participants. The main hazards in their job are physical agents - whole body and handarm vibration, noise, infrasound, unfavorable microclimate - extreme temperatures, draughts, sun radiation etc., chemical agents are: - carbon monoxide, sulphur dioxide, nitric oxide, aliphatic hydrocarbon, formaldehyde, ozone and etc. [1-3].

Mental and musculoskeletal exertion, eyestrain, also frequent stressful situations are the most influential ergonomic (psychophysiological) factors, affecting health and work capacity. Work safety and health are related directly to lifestyle, nutrition, addictions, and psychosocial factors.

The integrated and prolonged exposure to these factors affects health, workability and professional reliability of motor transport workers. No doubt all this has an impact on traffic safety, increased number of accidents, and develop severe psychological, moral and economical consequences $[4,5]$.

The analysis of motor transport workers' health sta-

\footnotetext{
* Discussion of results of programme "Transport: technologies, economic, environment, health"
}

tus revealed higher frequency of respiratory, musculoskeletal, peripheral nerves, cardiovascular, gastrointestinal diseases. Accident rates are also high $[6,7]$. More than $50 \%$ of drivers suffer from musculoskeletal disorders, manifesting in tension, pain, decrease of work capacity $[8,9]$.

The aim of this study is to investigate occupational, lifestyle and psychosocial factors of motor transport workers and evaluate the relationship between these risk factors and workers health.

\section{Study Objectives, Material and Methods:}

The study was carried out during the period 20012002 in 3 (three) urban motor transport companies, which had 1857 workers in total in 2002.

The specific questionnaire included a documental part, questions on lifestyle and psychosocial risk factors, occupational exposures and health status (all together 78 questions). It was made at Kaunas Medical University, at the Department of Environmental and Occupational Medicine.

1000 workers were recruited for the study and 788 have participated and answered the questionnaire (participation rate $78,8 \%$ ) (Table 1 ).

Physical, chemical and psychophysiological factors at the workplaces were measured and evaluated, following the methodology set by LR Government, Health 
Table 1. Size of occupational groups selected for the study of occupational exposures and health status

\begin{tabular}{|l|c|c|}
\hline \multicolumn{1}{|c|}{ Occupation } & Number & $\%$ \\
\hline Drivers & 371 & 47,1 \\
\hline Autolocksmiths & 100 & 12,7 \\
\hline Joiner's shop workers & 62 & 7,9 \\
\hline Electromechanics & 95 & 12,1 \\
\hline Others & 160 & 20,3 \\
\hline Total & 788 & 100,0 \\
\hline
\end{tabular}

Ministry, Social Security and Labor Ministry [10].

All the data was computerized and stored in Microsoft Exel 97. Frequency of variables was calculated using Epi Info for Windows statistical program. $c^{2}$ test and correlation analysis was made using SPSS statistical program [11].

\section{Results and Discussion}

According to the age all motor transport workers were divided into five standard groups. 20-29 y.a. (year age) workers made $9,9 \%, 30-39$ y.a. $-28,1 \%, 40-49$ y.a. $-32,9 \%, 50-59$ y.a. $-24,9 \%$, over 60 y.a. $-4,2 \%$. Young and middle age (30-59 y.a.) workers made the absolute majority $-85,9 \% .85,4 \%$ of employees were men, 14,6\% - women. Men drivers made up 85,4\%, electromechanic workers $-91,5 \% .6,6 \%$ of all respondents had primary, $31,7 \%$ - specific secondary, $46,0 \%$ secondary, 11,2\% - got higher and 4,4\% - had university education. $26,6 \%$ of participants had up to 9 year work experience, $30,4 \%$ - had 10-19 year experience, $23,8 \%-20-29$ year. $19,1 \%$ of workers had over 30 years total work experience. $59,3 \%$ of drivers mentioned their $10-29$ year total work experience. $78,2 \%$ of employees were married, $12,1 \%$ - single, $9,7 \%$ denoted 'the other' marital status (divorced or living with a partner).

The analysis of psychosocial factors and lifestyle revealed that only $3,8 \%$ of all respondents were entirely satisfied with their living conditions.

$63,5 \%$ of workers were satisfied; the distribution according to occupation among them was about the same, ranging from $63,0 \%$ - to $70,0 \%$. Unsatisfied were $32,8 \%$ of the respondents. Those, who were unsatisfied with living conditions, defined their health as " not entirely healthy" or "ill" ( $<<0,05$ ) (Fig 1). 46,0\% of all workers were smokers, 54,0\% - non-smokers. According to the occupation, the majority of smokers were drivers $-47,9 \%, 53,1 \%$ - auto locksmiths. Smokers of other professions constituted $32,3 \%-45,0 \% .60,7 \%$ of employees smoke at work, $39,3 \%$ - at home.

$83,8 \%$ of participants drink alcohol, $16,2 \%$ - do not use it at all. 14,65\% of joiner's shop workers and 14,3\% of auto locksmiths use alcohol several times per week. Only 3,3-6,3\% of other professions workers use alcoholic beverages a couple of times a week. $4,61 \%$ of participants

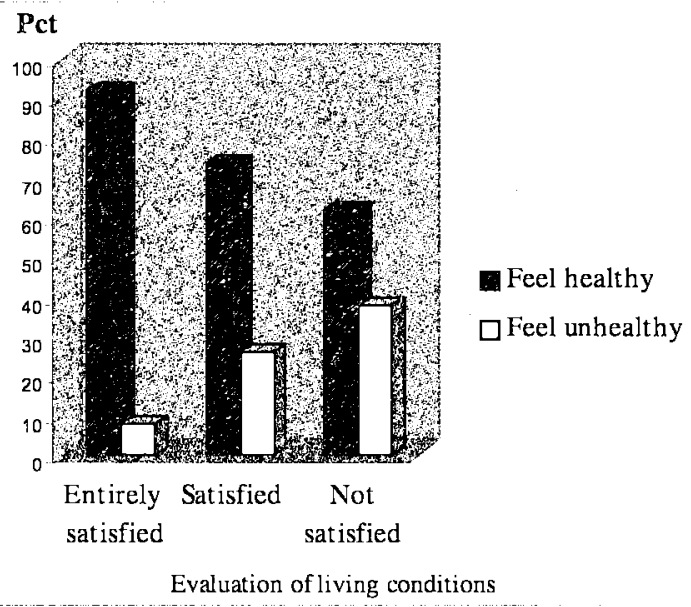

Fig 1. Relation between health status and living condition

drinks alcohol once a month. $44,5 \%$ - only several times per year. Although the questionnaire was anonymous, we are rather skeptical about the answers of motor transport workers. These results distinctly do not coincide with statistics of alcohol consumption in Lithuania.

Following physical activity tests, it is obvious that, $46,3 \%$ a workers consider themselves as physical active persons. They exercise every day or several times a week, they go in for sports or practice any other kind of physical activity.

The analysis of nutrition questions revealed, that the absolute majority $-83,8 \%$ have meals $2-3$ times per day, and $11,8 \%-4-5$ times per day, 3,8\% eat only once a day. Dry food with some beverages during lunchtime at the workplace is consumed by $82,5 \%$, while usual meal (with soup) is taken only by $17,5 \%$ of people. The worst nutrition was of drivers and auto locksmiths. $67,7 \%$ of drivers, $50,0 \%$ of auto locksmiths and $55,5 \%$ of electromechanics workers admitted, that due to specific work-time-schedules and poor menu at the companies bar, they do not have any possibilities for proper daily nutrition regimen.

The lack of sleep was indicated by $31,8 \%$ of all workers: $43,3 \%$ of drivers, $29,3 \%$ of autolocksmiths and $27,3 \%$ of electromechanical workers. Even $20,0 \%$ of employees feel drowsiness, $32,4 \%$ are in a bad mood, $26,2 \%$ - suffer from a frequent headache at work. The relationship between sleep duration, its quality and psycho emotional status at work, is statistically significant $(p<0,001)$. Stressful situations at work were experienced every day by $16,2 \%$, several times per week by $21,5 \%$ of workers. $27,5 \%$ of drivers and $10,2 \%$ of joiner's shop workers suffer from stressful situations every day, $25,0 \%$ of drivers and autolocksmiths - few times per week (Table 2). Sleep disorders, headaches and bad mood while on the job have a direct relation with a mental stress at work $(p<0,005)$.

The analysis of workplace conditions and ergonomic 
Table 2. Mental stress at a workplace

\begin{tabular}{|l|c|c|c|}
\hline \multirow{2}{*}{ Occupation } & \multicolumn{3}{|c|}{ Frequency of stressful situation } \\
\cline { 2 - 4 } & Everyday & $\begin{array}{c}\text { Few times } \\
\text { week }\end{array}$ & $\begin{array}{c}\text { Few times/ } \\
\text { month }\end{array}$ \\
\hline Drivers & $27,2 \%$ & $25,7 \%$ & $47,2 \%$ \\
\hline Autolocksmiths & $7,4 \%$ & $24,7 \%$ & $67,9 \%$ \\
\hline Joiner's shop workers & $10,2 \%$ & $12,2 \%$ & $77,6 \%$ \\
\hline Electromechanics & $1,4 \%$ & $10,8 \%$ & $87,8 \%$ \\
\hline All workers & $16,2 \%$ & $21,5 \%$ & $62,3 \%$ \\
\hline
\end{tabular}

factors showed, that even $75,7 \%$ of workers of the main professions are satisfied, and $17,2 \%$ - are not. The majority of unsatisfied people are among drivers, $-(20,3 \%)$ autolocksmiths $-22,2 \%$ and electromechanic workers $(17,4 \%)$. Microclimate of the workplace (premises), air pollution, noise, vibration, heed strain, long working hours are major factors due to which motor transport workers refer existing work conditions to bad ones. However the subjective evaluation of occupational exposures vary among the professions.

Drivers emphasize harmful factors such as heed and eye strain, workplace microclimate, exposure to chemicals (diesel fuel, cooling oil), noise, vibration and too long working hours. As the most harmful autolocksmiths stress such factors as inappropriate microclimate, noise and exposure to chemicals (Table 3 ).

The majority of motor transport workers $(71,3 \%)$ work about $8 \mathrm{~h}$ per day, the others $(28,7 \%)$ spend more than $8 \mathrm{~h}$ at work. Even $60,5 \%$ of drivers' workday is longer than $8 \mathrm{~h}$. We found, that over $8 \mathrm{~h}$ workday duration was related to negative evaluation of the health status $(p<0,002)$, more frequent health complaints $(p<0,05)$ and mental stress at work $(p<=0,001)$.

Table 3. The most unsatisfactory workplace conditions for the workers of main occupations

\begin{tabular}{|l|c|c|c|c|}
\hline $\begin{array}{l}\text { Workplace } \\
\text { conditions }\end{array}$ & Drivers & $\begin{array}{c}\text { Autolocks- } \\
\text { miths }\end{array}$ & $\begin{array}{c}\text { Joiner's } \\
\text { shop } \\
\text { workers }\end{array}$ & $\begin{array}{c}\text { Electrome- } \\
\text { chanics }\end{array}$ \\
\hline Day shift & 28,3 & 3,0 & 9,7 & 2,1 \\
\hline Evening shift & 7,3 & 0,0 & 6,5 & 1,1 \\
\hline Night shift & 10,5 & 1,0 & 8,1 & 5,3 \\
\hline $\begin{array}{l}\text { Long working } \\
\text { hours }\end{array}$ & 34,5 & 13,0 & 16,1 & 24,2 \\
\hline $\begin{array}{l}\text { Monotonous } \\
\text { work }\end{array}$ & 22,1 & 8,0 & 12,9 & 1,1 \\
\hline $\begin{array}{l}\text { Uncomfortable } \\
\text { work place }\end{array}$ & 18,3 & 11,0 & 9,7 & 12,6 \\
\hline Heed strain & 49,9 & 18,0 & 24,2 & 20,0 \\
\hline Visual intensity & 49,1 & 16,0 & 22,6 & 9,5 \\
\hline Hearing intensity & 13,7 & 9,0 & 3,2 & 2,1 \\
\hline Noise & 31,3 & 47,0 & 30,6 & 27,4 \\
\hline Vibration & 45,8 & 18,0 & 21,0 & 7,4 \\
\hline Chemicals, fuels & 46,6 & 45,0 & 29,0 & 28,4 \\
\hline Microclimate & 47,2 & 60,0 & 53,2 & 41,1 \\
\hline
\end{tabular}

Having analyzed the subjective opinion defining the personal health of 788 motor transport employees, such results were received: $69,9 \%$ thought they had a 'good health', $28,6 \%$ considered themselves as 'not so healthy' and 2,3\% felt 'sick' (Fig 2.). 70,7 \% of drivers and 66,0\% of electromechanics defined health status very positively; the worst evaluations were given by joiner's shop/workers $(49,1 \%)$ and autolocksmiths $(36,4 \%)$. During the last one year period, $39,0 \%$ of motor transport employees visited a doctor (except dentist) once $51,0 \%$ made a visit twice, $10,0 \%$ - three or more times. The aim of the study of motor transport workers health problems concerning the most frequent and health disorders complaints was to define a possible relation between the occupation and manifestation of impact of occupational exposures.

Even $32,7 \%$ of employees had various symptoms of CNS disfunction (headache, sleep disorders, drowsiness at work). 19,6\% suffered from hypertension (high blood pressure). $22,7 \%$ of respondents denoted cough problems and bronchitis. A significant relation $(\mathrm{p}<0,004)$ was found between respiratory symptoms and drivers and autolocksmiths. 17,3\% of drivers had gastrointestinal disorders (heartburn, gastritis). Among all motor transport professions even $63,3 \%$ of drivers had a significantly higher $(p<0,05)$ number of musculoskeletal problems (neck, back, waist pain). CNS dysfunction among drivers $(53,1 \%)$ was also more frequent $(p<0,05)$ (Table 4$)$.

We asked all the workers "which symptoms of health disorders or ailments you relate to workplace conditions". $17,4 \%$ of all workers and $26,7 \%$ of drivers affirm, that all 'cold' diseases, common cold and bronchitis, are linked with the conditions at work. $23,0 \%$ of all transport workers and $37,5 \%$ of drivers noted, that neck, back and waist pains are related to job task and poor ergonomical workplace design $(p<0,002)$. The analysis showed, that there is a statistically significant association between the frequency of back and waist pain and human age and total work experience (Fig 2).

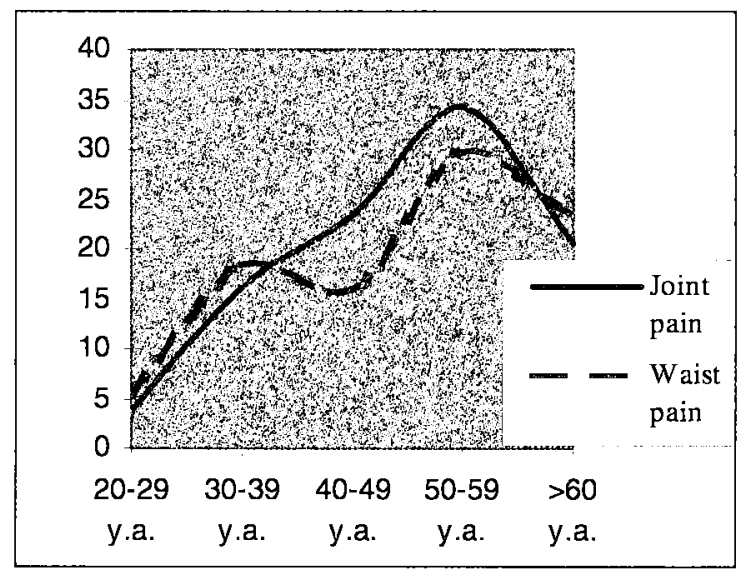

Fig 2. Prevalence of joint and waist pain in diferent age groups 
Table 4. Comparison of some health problems of workers of the main occupation

\begin{tabular}{|c|c|c|c|c|}
\hline Occupation & Drivers & $\begin{array}{l}\text { Autolock- } \\
\text { smiths }\end{array}$ & $\begin{array}{l}\text { Joiner's } \\
\text { shop } \\
\text { workers }\end{array}$ & $\begin{array}{l}\text { Electro- } \\
\text { mechanics }\end{array}$ \\
\hline Headache & $18,6^{*}$ & 13,0 & 16,1 & 13,7 \\
\hline Sleep disorders & 20,2 & 10,0 & $21,0^{* *}$ & 4,2 \\
\hline $\begin{array}{l}\text { Drowsiness at } \\
\text { work }\end{array}$ & $14,3^{*}$ & 2,0 & 9,7 & 3,2 \\
\hline Hypertension & 21,9 & 17,0 & 14,5 & $20,0^{*}$ \\
\hline \begin{tabular}{|l|} 
Cough, \\
bronchitis
\end{tabular} & $26,1^{* *}$ & $30,0^{*}$ & 16,1 & 16,8 \\
\hline $\begin{array}{l}\text { Gastrointestinal } \\
\text { problems }\end{array}$ & $17,3^{*}$ & 14,0 & 6,5 & 9,5 \\
\hline Neck pain & 11,3 & 9,0 & 6,5 & 8,4 \\
\hline Back pain & $25,6^{*}$ & 16,0 & $25,8^{*}$ & 13,7 \\
\hline Waist pain & $26,4^{*}$ & 14,0 & 14,5 & 13,7 \\
\hline
\end{tabular}

$*-p<0,05$ comparing with other occupations

Headaches and gastrointestinal disorders were more frequent among drivers; the result was statistically significant $(\mathrm{p}<0,002)$. These health problems could be caused by irregular, dry food, malnutrition, smoking and other risk factors characteristic for this type of workers. There is a statistically significant relation between driver's profession and mental stress experienced every day $(p<0,004)$.

\section{Conclusions}

1. The lifestyle of the motor transport workers is not healthy: $46,0 \%$ are smokers, $83,8 \%$ are drinkers, $52,8 \%$ are physically not active, $82,5 \%$ have irregular, insufficient alimentation, 31,8\% lack sleep, 27,0\% of drivers experience stressful situations at work every day.

2 . The most hazardous factors according to the workers are low ambient temperature, draughts, exposure to diesel fuel and cooling oil, noise, vibration, heed and musculoskeletal exertion.

3. $31,0 \%$ of the motor transport workers have health problems. Musculoskeletal problems prevail among them $(46,2 \%)$, followed by respiratory $(22,7 \%)$, gastrointestinal $(17,3 \%)$ and central nervous dysfunction $(32,7 \%)$.

4. Study results show, that there is a statistically significant relation between driver's, workshop, worker's occupation, poor ergonomics, elder age and great work experience and musculoskeletal disorders $(p<0,02$ 0,002). Respiratory and gastrointestinal disorders are significantly more common among drivers and autolocksmiths $(\mathrm{p}<0,05-0,002)$.

\section{References}

1. Transport, Environment and Health. WHO Regional Publications. Europeen Series, No 89.

2. Occupational diseases. Guide for physicians. (Профессиональные заболевания. Руководство для врачей. Т. 2. Под ред. акад. РАМН проф. Н. Ф. Измерова). Moscow: Medicina, 1996 (in Russian).

3. Pajarskienė, B.; Jankauskas, R.; Mačiulyte, N. The Psychosocial Work Factors Influence on Occupational Stress among Passenger Transport Drivers in Vilnius. Public Health (Visuomenès sveikata), 2003, 2(21), p. 13-17 (in Lithuanian)

4. Peplonska, B.; Szeszenia-Dabrowska, N. Occupational Diseases in Poland, 2001. Intern. J. of Occup. Medicine and Environmental Health, Vol 15 , No 4, 2002, p. 337 345 .

5. Obelenis, V. Professional stress and health. Occupational safety and health. Vilnius, 1998.

6. Obelenis, V.; Bagdonienè, T.; Mačionis, A. and others. Occupational medicine (Darbo medicina). Kaunas, 2002 (in Lithuanian).

7. Mačiulyte, N. Work and health of workers of motor transport. Health (Sveikata), No 7-8, 2000 (in Lithuanian).

8. Jankauskas, R.; Mačiulytè, N. Prevalence of musculoskeletal disorders among drivers of Vilnius city. Public Health (Visuomenès sveikata), No 1(18), 2002 (in Lithuanian).

9. Zejda, J. E.; Stasiow, B. Cervical spine degenerative changes (narrowed intervertebral disc spaces and osteophytes) in coal miners. Intern. $J$. of Occup. Medicine and Environmental Health, 2003, 16(1), p. 49-53.

10. Methodics for evaluation of psychophysiological (ergonomic) factors. Approved by Occupational Medicine Center of Hygiene Institute 1997 May $12^{\text {th }}$.

11. Čekanavičius, V.; Murauskas, G. Statistics and its applications (Statistika ir jos taikymai). Vilnius, 2001 (in Lithuanian). 